DOI https://doi.org/10.30525/978-9934-588-90-7-73

\title{
INTERCULTURAL COMMUNICATION IN THE CONDITION OF MODERN GLOBALIZATION PROCESSES
}

\author{
Verizhenko D. I. \\ $3^{\text {rd }}$ year Student \\ University of State Fiscal Service of Ukraine \\ Gnativ O. R. \\ $2^{\text {nd }}$ year Student \\ State University Fiscal Service of Ukraine \\ Goncharenko M. V. \\ $3^{\text {rd }}$ year Student \\ State University Fiscal Service of Ukraine \\ Irpin, Kyiv region, Ukraine
}

Intercultural communication has existed since ancient times, and also served as a tool for mutual understanding of different cultures. Intercultural communication contributed to the establishment of various international relations, as it was one of the factors in the development of various cultures. The modern world is more and more becoming globalized. In modern conditions, communication among peoples has acquired not only a global character, but also requires such a humanistic positioning, which, thanks to intercultural communication, enables a person to be successfully developed on the basis of the universal and national values' unity.

This article considers the development and position of the cross-culture communication in the modern world under conditions of globalization processes. It should be noted, that this problem was researched by such scientists as D. Lall, Pomeranets G. S., Davydova Yu. M., Kutyreva V. A., Bondarenko S., Golovina N., Lurie S., Myrolyubov O., Pluzhnyk I. It is worth mentioning that in Ukraine the subject field of investigating the "intercultural communication" issue is just being formed.

To better understand and reveal the chosen problem, we will first analyze the general theoretical aspect of intercultural communication. Intercultural communication is a process of communication (verbal and nonverbal) of people (groups of people) belonging to different national linguistic and cultural communities, usually using different idioethnic languages, feel the linguistic and cultural "alienation" of a communication partner, have different 
communicative competence, which can cause communicative failures or a cultural shock in communication [4, p. 9].

Instead, Kost' S. P. determines the intercultural communication as a social phenomenon, the essence of which is a constructive or destructive interaction between representatives of different cultures (national and ethnic), subcultures within a clearly defined spatio-temporal continuum. [2]

The subject of intercultural communication includes contacts that are made at different levels, in different audiences, in two-way, many-sided, global aspects. The aim of intercultural communication should be to create conditions for the development of constructive dialogue, which is an equal representative of other cultures.

Another very important concept for our research is the process of globalization. Globalization is a modern transformation process in the spatial organization of local, regional, and world economic and relevant social relations. Therefore, it is a process of mass and large-scale social, political and economic activity beyond the borders of individual states to regions and continents [1, p. 118]. One of the globalization characteristic features is the connection of both individuals and individual civilizations. Globalization of social development is caused by increasing intensity of contacts and relations such as: economic, socio-political, cultural, scientific, technical ones, etc. The globalization process leads to the formation of new cultural forms, values, examples of behavior and activities. As a result of the process of integrating different ethnic cultures into one world culture on the principles of development of communicative means, economic and social relations a culture globalization has been spread. Cross -cultural communication obtains a special status, the basis of all these relations among civilizations is intercultural communication, because the need of peoples for cultural understanding, the desire to know each other's spiritual world lead to activation of communicative processes that acquire a systemic character.

During intercultural communication, all these processes are created through the expansion of contacts between government institutions, social groups and individual visitors from different countries and cultures, the borrowing of cultural values and changes in the cultural environment as a result of migration [3].

Due to the development of science and technology, the communication means and the mass media can easily cross the state and cultural borders. This technical property directly affects intercultural communication, and also reactivates discussions about the sovereignty of cultures. The effects of the global communication development have been the focus of UNESCO since the early 1970s. There is a concern that the West which is led by American multinational corporations, has monopolized the global communication system to such an extent that it has done significant damage to the welfare and cultural 
identities of less powerful countries. An example of such influence is Ukraine and the state of its modern culture, which is oversaturated with images of Western culture, displacing national traditions, and begins to lose and forget its own culture. Tendences in the leveling of the interests of states and cultures that accompany the process of globalization should be regulated or minimized through the realization of various optimal actions at the level of international relations [3]. Analyzing all the mentioned above, we can say that only by finding consensus can humanity solve global problems and protect itself against self-destruction.

A really important element of globalization processes that is beginning to form new cultural territories is deterritorialization. Deterritorialization in its narrow meaning is "the destruction of natural links among culture, geography and social territory". In wide meaning, deterritorialization is the partial destruction of cultural structures and relations, environments and representations. A negative manifestation of deterritorialization is migration of people's groups from underdeveloped to highly developed countries, searching for a better life, but in the context of intercultural communication it causes cultural misunderstandings. In the contemporary world which is characterized by really fast globalization processes, much attention should be paid to the problem of refugees. Sometimes this can have a positive effect, in particular, on the formation of diasporas in new countries, that bringing new cultures to a new country, which are not given the characteristics of nature, but are perceived by society.

To make a conclusion, we can say that intercultural communication in the conditions of globalization is dynamic and multifaceted, it is one of the most important factors of socio-cultural changes. The globalization process leads to appearing cultural forms, new values, examples of behavior and activities, that is why intercultural communication is a tool for interaction between different cultures. Globalization is a dynamic phenomenon, therefore forms, methods and means of people's communication are constantly changing, which in its turn changes the nature of communication. First of all, expansion of international contacts involves knowledge of foreign languages. However, this is not enough. In order to avoid barriers in communication with representatives of other countries and different cultures, it is necessary to know about their cultural characteristics.

\section{References:}

1. Encyclopedia of the History of Ukraine: Vol. 2: G - D / Editor. : Smoliy V.A. (chairman) et al. NAS of Ukraine. Institute of History of Ukraine. Kyiv : Naukova Dumka Publishing House, 2004. 688 p. 
2. Kost S.P. Intercultural communication as a manifestation of social interaction [Electronic resource]. URL: http://www.rusnauka.com/ 6_NITSB_2010/Philologia/59572.doc.htm

3. Prikhodko A.I. Intercultural communication in the context of globalization. Actual problems of philology and pedagogical linguistics. 2011. P. 163-166.

4. Dictionary of terms of intercultural communication / Batsevich F.S.; Ministry of Education and Science of Ukraine, L'viv I. Franko National University. Kyiv : Dovira, 2007. 205 p.

DOI https://doi.org/10.30525/978-9934-588-90-7-74

\title{
THE CONCEPT OF POSITIVITY IN PRIVATE CLASSIFIEDS OF THE SECTION 'FOR HOME'
}

\author{
Husar M. V. \\ Candidate of Philological Sciences, \\ Associate Professor at the Department of English Language \\ National University of "Kyiv-Mohyla Academy" \\ Kyiv, Ukraine
}

The topic of our research is defined by the relevance of learning the concepts which is caused by the present-day linguists' interest to such problems of cognitive linguistics as language world picture, language personality, language discourse, conceptualization. The object of the investigation is the private classifieds published in British newspapers online. The novelty is explained by the fact that the concept positivity in private classifieds is analyzed for the first time. The component method of concept analysis is used.

Today there are several definitions of the concept. One of the most popular among the national linguists is one given by O. Kubriakova. 'Concept is a term, which serves to explain the units of mental ... resources and that informational structure, which reflects the knowledge and experience of the human; operative meaningful unit of the memory, mental lexicon, conceptual system and language of mind (lingua mentalis), the whole world picture, reflected in the human psyche. The notion of the concept of the whole world picture corresponds to the realization of those senses operated by human while thinking and introducing the contents of experience and knowledge, the contents of the results of human activity world cognition as some "quants of knowledge' [3, p. 90]. 